\title{
Iconography of the Mexico City Metro
}

\author{
Monika Brenišínová
}

\begin{abstract}
This article is dedicated to the iconography of the Mexico City metro. The aim is to present the unique picture signage and interpret it within the history of Mexico and its capital. The article approaches the metro signage as a form of symbolic communication. It gradually introduces each of the metro icons and interprets them in terms of Erwin Panofsky's iconology. These classical methods of art history enable not only the description of Mexico City metro signage but also the interpretation of it in the context of important economic, social and historical events of the country. In order to make the text comprehensible, I have divided it into four chapters. In conclusion, the article claims that the metro signage provides insight into Mexican history. However, it also shows that the Mexico City Metro should be viewed as a showcase of the Mexican state and its power.
\end{abstract}

KEY WORDS Iconography, iconology, Mexico City, metro, history

\section{As a user of the Mexican metro ${ }^{1}$}

I was fascinated by the simplicity of the system of metro signage. This system works - in addition to the usual tools, such as color and title - with icons. Every individual symbol refers to the toponymy of the city, and it is somehow characteristic of the station. Thus, this picture signage facilitates the orientation of persons who do not know the toponymy of the city, do not speak Spanish or simply cannot read. Furthermore, due to their importance, the metro icons create not only a map of the Mexican metro, but also a rich picture of Mexican history. In this article, I will present and analyze every individual Mexico City Metro icon in terms of Erwin Panofsky's iconology. Thus, I conceive of the metro signage as a system of signs and symbols, which transmit to the passengers information beyond the standard framework of traffic signage. In order to make the present text comprehensible and clearly arranged, I have divided it into four chapters: the first chapter speaks about the symbols referring to the pre-Columbian period of ancient Mexico; the second chapter relates to the conquest and

Sociální studia. Department of Sociology FSS MU, 1/2015. S. 75-92. ISSN 1214-813X.

1 The Mexico City Metro is officially called Sistema de Transporte Colectivo (in English, "System of Public Transport"), but is commonly known and referred to as "the metro." The term "metro" was born in France in the beginning of the $20^{\text {th }}$ century as an abbreviation of the French phrase "chemin de fer métropolitain." While the English terms "underground" and "subway" are used mainly in English-speaking countries, the term "metro" is used internationally (see Ríos 1973: 55). 
colonization of New Spain; and the third section describes the metro stations in relation to the birth of the modern national and independent state of Mexico. The final chapter speaks about the processes of modernization of the capital city during the last two centuries. To conclude, I discuss and assess the results presented in the article.

The idea of constructing an electric underground railway in the capital city of Mexico was born in the 1950s, if not earlier. Nevertheless, the high cost of construction and the lukewarm attitude of governments meant that the foundations of the first metro line were not laid until almost 20 years later - in 1967. ${ }^{2}$ As a matter of fact, the city's transport infrastructure was failing at that time. This was due to the fact that the population of Mexico City had been rising steeply and precipitously, and the transport system was unable to cope with the heavy demands placed upon it. ${ }^{3}$

The history of the graphical conception of the Mexican metro is associated with the $19^{\text {th }}$ Summer Olympic Games, which were held in Mexico City in 1968. Since the Mexican state did not have enough funds to compete with the pompous Olympic Games held in Japan four years earlier in 1964, it decided to stake the money on the graphic presentation and promotion of the Games, rather than on the expensive construction of sumptuous Olympic buildings as was usually the case. Ultimately, this strategy proved to be very successful, because the system of the Mexican Olympic Games signage became famous and internationally recognized throughout the world (Figure 1).

The Mexico 1968 Olympic Games signage was based on the use of simple picture symbols representing each individual sports event. The creator of the signs was American designer Lance Wyman (born in 1937), who chose this way to work with symbols intentionally (Wyman 2005b), as shown with his own words:

...two basic ways we learn to represent and communicate the objects, actions and feelings in our lives are with words and images. Words are an effective method of communicating complicated interrelated ideas. It is symbols however that can communicate across the language barriers created by words (Wyman 2004).

2 The decree declaring the creation of a Public Transport System (from Spanish, Sistema de Transporte Colectivo) in the Federal District consisting of an electric railway - both underground and surface - was issued in the diary Diario Oficial on 29 March 1967. The decree was signed by Gustavo Díaz Ordaz, the then Constitutional President of the United Mexican States (see Ríos 1973: 17, 55; Sistema de transporte colectivo. Decreto de Creación del Sistema de Transporte Colectivo. [online]. n. d. [cit. 05. 04. 2014]. Accessible at: http://www.metro.df.gob.mx/organismo/ mjdecreto.html).

3 According to the official census, the population of Mexico City reached 4.7 million in 1968. In two years it increased to 6.9 million and in 1971 to 8.5 million. See the official website of the National Institute of Statistics and Geography INEGI (from Spanish, Instituto Nacional de Estadística y Geografía) (Ríos 1973: 56; Instituto nacional de estadística y geografía. Dinámica. [online].n.d. [cit. 05. 04. 2014]. Accessible at: http://cuentame.inegi.org.mx/monografias/ informacion/df/poblacion/dinamica.aspx?tema $=$ me\&e=09). 
Figure 1: Lance Wyman, Icons of Mexico 68 Olympic Games, 1968

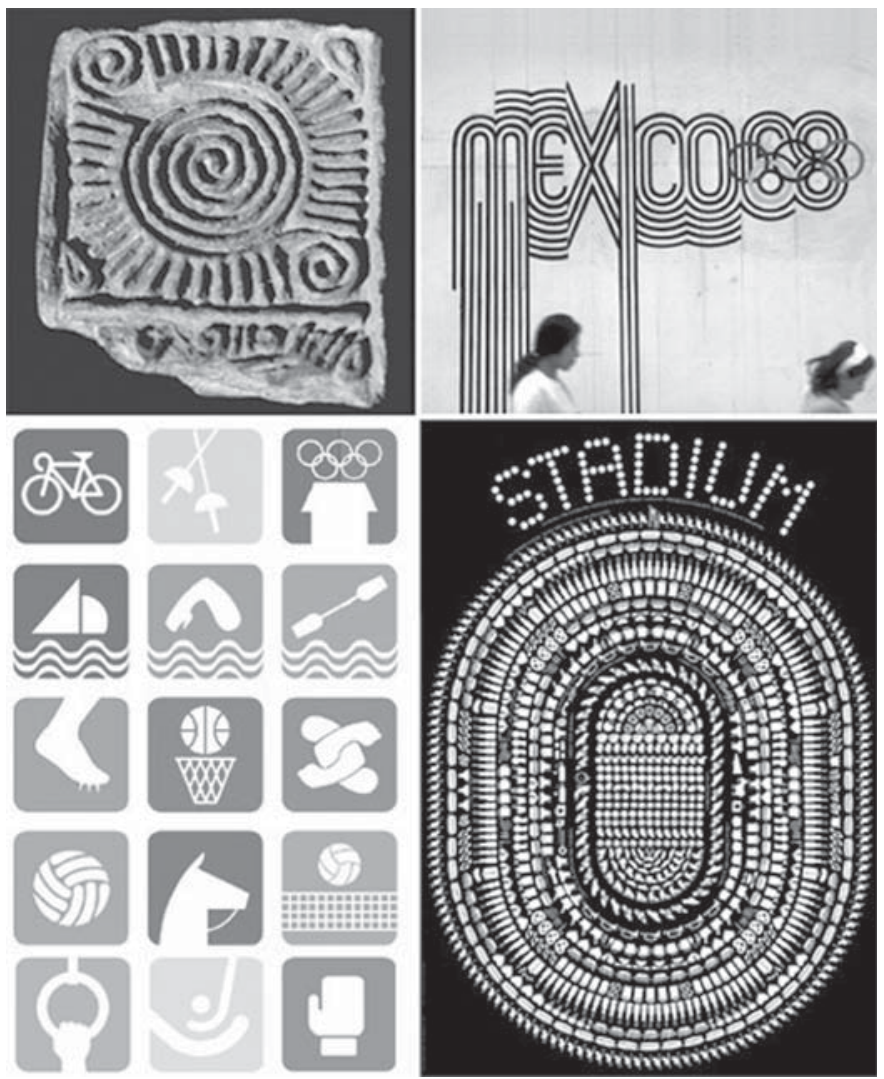

Source: http://www.designboom.com/design/lance-wyman-explains-wayfinding-systems/.

This Mexico 1968 Olympic Games signage facilitated the orientation of thousands of foreigners, who came to the Mexican capital to see the Olympic Games without any knowledge of Spanish or the city. The signage was such a success that the search and selection for an appropriate designer for the Mexico City Metro sign system led (without any doubts) to Wyman.

The signage of the Mexico City Metro was the result of work by a team of architects, photographers and graphic designers (above all, Arturo Quiñones and Francisco Gallardo). The team was led by Lance Wyman, who worked in $\mathrm{ISTME}^{4}$ under the coordination of architect Pedro Ramírez Vázquez. Together they brought to light the original conception

4 The architecture, as well as the designs of trains and stations, was the responsibility of the Mexican Society of Engineers ISTME (from Spanish, Ingenieros en Sistemas de Transporte Metropolitano) (see Sistema de transporte colectivo. Lance Wyman y la comunicación visual en el metro. [online]. n. d. [cit. 05. 04. 2014]. Accessible at: http://www.metro.df.gob.mx/red/iconografia.html). 
of the graphic and visual design, including the logo of the Mexican metro and the icons of every metro station.

The singularity of the Mexican underground railway signage lies in the fact that it works with more tools than usual. Firstly, it is a logo of the Mexico City Metro. Secondly, the combination of the number and the color, which is characteristic of the line. And thirdly, the system of icons, which is specific to each individual metro station.

The logo of the Mexican metro was designed by cutting the three lines of the first letter of the word metro "M" into the form of the City square commonly called "Zócalo." Thus the logo has the form of the letter " $\mathrm{M}$ " executed in the color orange, which lies in a black field in the form of a square. The letter "M" represents the first three lines of the metro as they pass through the center of Mexico City, and its orange color refers to the color of the metro cars (Figure 2).

Figure 2: First three lines of the Mexico City Metro and its logo in form of the letter "M"

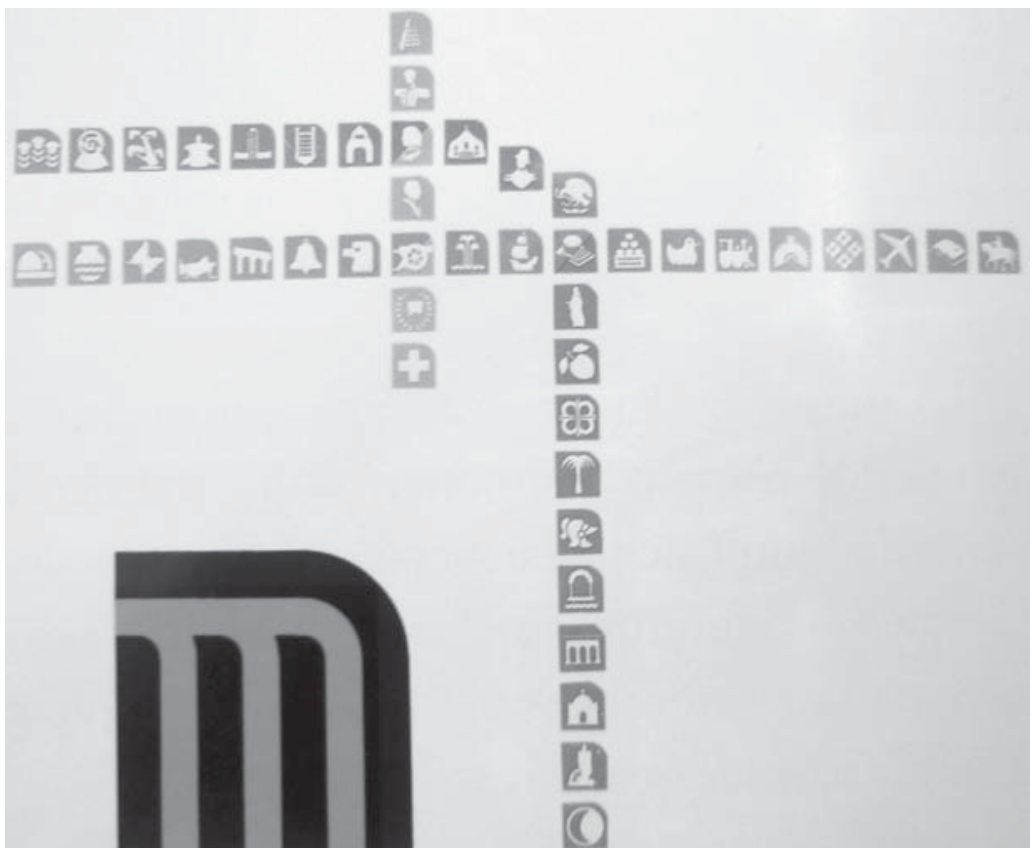

Source: adapted from Borja Navarerete, Angel. Treinta años de hacer el Metro

5 The main city square is officially called Plaza de la Constitución (in English, "Constitution Square"). Its informal and more common name is Zócalo (in Spanish, "plinth"), because of the plinth of the Independence Monument, which was supposed to stand at the city square, but was never completed and finally was removed from the square. For more on the history of the name Zócalo, see Sistema de transporte colectivo. Zócalo. [online]. n. d. [cit. 05. 04. 2014]. Accessible at: http://www.metro.df.gob.mx/red/estacion.html?id=33. 
Each line has a specific number and color. This combination facilitates the simple identification of the line and its location. If we take a look at the Mexico City Metro plan, ${ }^{6}$ we see that the colors of the first three lines are: pink, dark blue and olive-green. When we compare this with Europeans metros - such as the Prague Metro plan (DPT n. d.), whose colors are green, yellow and red - we see that the graphic design of the Mexico City Metro reflects a Mexican color palette based on bright colors of animal and mineral origin. This is because pink - especially in the form of the Mexican rose - forms an integral part of traditional Mexican culture. Examples can also be seen by way of traditional clothing.

However, the most interesting part of the Mexican Metro signage is the metro station icons, which are accompanied by the name of the station in written form, and by the color and number of the given line. The icon is a graphic symbol (usually in the form of a small picture) denoting the name of the station. The metro station symbols are based on the toponymy or history of the city. This means that they refer to the place where the station is located (the station usually bears the name of a nearby street, square, park, monument, or some important building or office, etc.), or alternatively, an outstanding event or personality of Mexican history $^{7}$ (Figure 3).

Figure 3: Icons of the first line of the Mexico City Metro
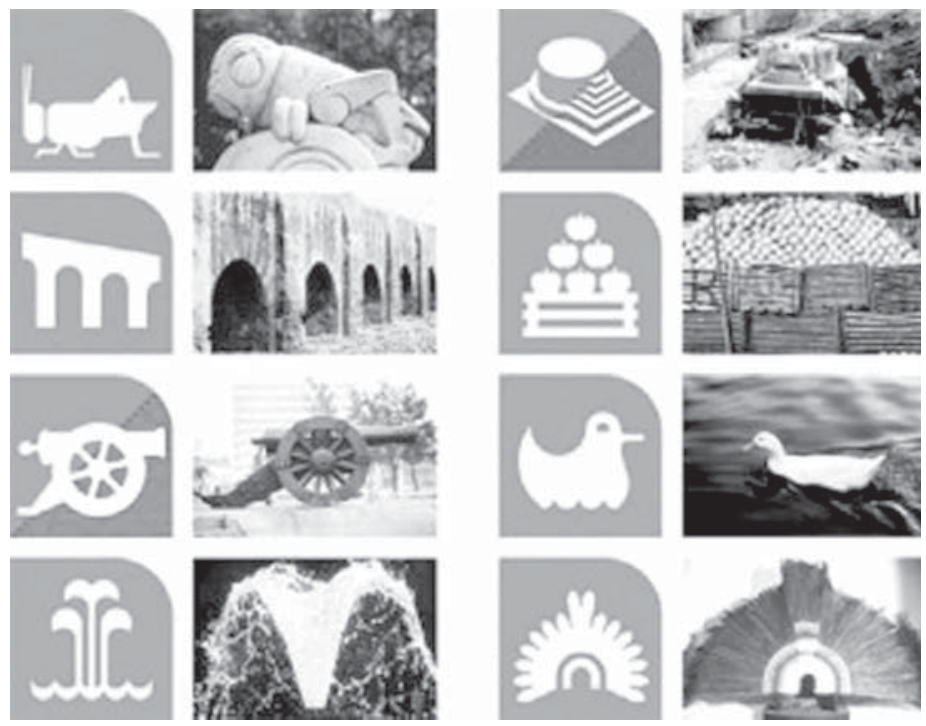

Source: http://art.webesteem.pl/9/wyman_en.php

$6 \quad$ See Sistema de transporte colectivo. Plano de red web. [online]. n. d. [cit. 05. 04. 2014]. (Accessible at: www.metro.df.gob.mx/imagenes/red/redinternet.pdf).

$7 \quad$ Regarding the system of Mexican metro signage (see Borja 1997: 210-211; Sistema de transporte colectivo. Lance Wyman y la comunicación visual en el metro. [online]. n. d. [cit. 05. 04. 2014]. Accessible at: http://www.metro.df.gob.mx/red/iconografia.html). 
Here, I should remark that this original solution was not only the product of Lance Wyman's genius. It was also designed to ensure the orientation of travelers in the tangle of underground lines and stations, especially for the illiterate population of Mexico, whose numbers reached $26 \%$ during the $1970 \mathrm{~s}^{8}$

Thus, the advantage of the Mexico City Metro signage consists solely in the fact that it is independent of language and its written form, due to the fact that it deals with picture icons. This unique quality allows for better orientation in the knotty system of the Mexican metro lines and stations, especially for foreigners, illiterates and preschool children. While for illiterates and small children the stations' names are illegible, for foreigners they are frequently too abstract to be remembered, as they do not know the language, or the toponymy of the city and its history.

Let's now have a look at one concrete example: the station Chapultepec, which lies along Line 1. Its name refers to the nearby park called Bosque de Chapultepec, which means "grasshopper hill"9. We will try to imagine the passengers of different nationalities and ages, such as a Mexican going to Chapultepec, his preschool child to a grasshopper and foreigners (for example a Frenchman) going to the "criquet." The reader might admit that this metro signage has many advantages to offer.

In the majority of cases the metro icons depict some urban architecture (such as famous buildings, monuments, bridges or nearby streets, places, etc.), human figures, or animals and plants. According to the theory of Erwin Panofsky (1981: 33-51), a German art historian and founder of modern iconology, I will approach the Mexico City Metro signage as a form of symbolic communication. Panofsky distinguished three different levels of art-historical understanding of art. The first basic level consists of the perception of a pure form of a piece of art and does not require any specific interpretive ability (e.g. the Chapultepec station logo depicts a grasshopper). The second level is the identification of the iconographic theme. Panofsky called this an iconographic description, and because the iconography is conventional, the iconographic description requires knowledge of the culture and its art (e.g. the grasshopper refers to the nearby park Bosque del Chapultepec, in English "grasshopper hill"). The third and last level presents the iconology, or the iconological analysis, which involves revealing the significance (or content) of some piece of art. Iconological analysis requires a deep knowledge of the history of the given culture, preferably based on the study of written sources. And it is just this significant quality of the Mexican Metro icons, by which the Mexican underground plan creates not only an extensive web of metro lines, but also a meaningful picture which speaks volumes about the history of the Mexican state and its capital city, at which we will now take a more detailed look.

8 On the problem of illiteracy in Mexico see Instituto nacional de estadística y geografía. Analfabetismo. [online]. n. d. [05. 04. 2014]. Accessible at: http://cuentame.inegi.org.mx/poblacion/ analfabeta.aspx?tema $=$.

9 On the iconography of the Mexico City Metro stations see Sistema de transporte colectivo. Estaciones [online]. n. d. [05. 04. 2014]. Accessible at: http://www.metro.df.gob.mx/red2/ index.html\#es. 
In view of the size of the Mexico City Metro, ${ }^{10}$ and the limits to the length of this paper, I will limit myself to analyzing the first three metro lines: Line 1 (pink), whose construction started in 1969 (Ríos 1973: 17) and which now has 20 stations; and Lines 2 and 3, which were built one year later in 1970 (Ríos 1973: 18). The color of the second line - which at present comprises 24 stations, is deep blue, and the third line, which currently has 21 stations - is olive (Figure 2). Now that we have defined the scope of this paper, we can approach the iconographic description and iconological analysis of symbols.

\section{The Aztec Empire}

Perhaps the most poetic icons are those whose names originate in the Aztec toponymy of the city. These include several stations on Line 1, among them: the station Tacubaya - whose name in Nahuatl, ${ }^{11}$ the language of ancient Aztecs, means "where water joins," and thus is symbolized by a water bowl; then Juanacatlán, ${ }^{12}$ or the "place of butterflies," whose sign contains a butterfly; and finally Pantitlán station, whose name means "between flags" and in its logo we see a silhouette of two flags. In addition, we can include in this group the interchange station Tacuba, which lies along Lines 2 and 7. Its name means "plants blooming on the plateau" and the station is represented by a picture of three flowers. And the Line 3 station Coyoacán, or the "place of coyotes," whose logo portrays a coyote.

In fact, there are more icons which relate to the pre-Columbian period of Mexican history, among them the icons of the first line stations Cuahtémoc and Moctezuma along with the second line station Cuitláhuac, which bear the names of the three last Aztec rulers. The icons of these stops depict the attributes of these sovereigns. The first one - Moctezuma station was named in the honor of the famous Aztec emperor Moctezuma II, who met with Hernán Cortés, the Spanish conqueror and excellent military strategist, in 1520. Cortés captured and removed him from control over his vast empire, which had been built by Moctezuma's ancestors over three centuries. ${ }^{13}$ The station emblem depicts a well-known and splendid feathered headdress traditionally attributed to Moctezuma, ${ }^{14}$ which stands as a classic example

10 At present, the Mexico City Metro comprises 12 lines, 195 stations and $226.49 \mathrm{~km}$ of routes. It is the second largest metro in North America, after the New York City Subway (see the note 9).

11 The Nahuatl tongue is a group of languages indigenous to Mesoamerica, which belong to the UtoAztecan language family. At present it is spoken by 1.5 million people, who come predominantly from Central and East Mexico (see Instituto nacional de estadística y geografía. Lenguas indígenas en Méxicoy hablantes (de 5 años y más) al 2010. [online]. n. d. [05. 04. 2014]. Accessible at : http://cuentame.inegi.org.mx/hipertexto/todas_lenguas.htm).

12 In fact, the name of this station comes from the Nahuatl word Xonacatlan, which correctly means "place of onions," but is sometimes mistakenly translated as "place of butterflies."

13 The Aztec Empire was an alliance of city-states and thus did not have exact borders like modern states. However, we can say that it was situated in central and southern Mexico (see Bernal 2000, 2009: 238-239; Opatrný 2003: 18-23).

14 Moctezuma's feathered headdress is assembled from five hundred quetzal feathers taken from 250 birds. This feather headdress is one of the best examples that have survived up to the present. 
of Aztec feather art, ${ }^{15}$ and whose replica can be admired at the Mexican National Museum of Anthropology and History. Cuitláhuac station ${ }^{16}$ was named after Moctezuma's relative, the penultimate Aztec ruler. The station logo portrays a chimalli ${ }^{17}$ battle shield, which commemorates the infamous historical event known as "The Night of Sorrows," 18 during which Cuitláhuac led the first Aztec rebellion against the Spaniards. The symbol of the last station of this trio depicts the head of an eagle, because the name Cuahtémoc, the truly final Aztec ruler, means "descending eagle" in Nahuatl.

As we have seen, these symbols reveal not only the original meaning of the local names, which would be otherwise shrouded in mystery for those without any knowledge of Nahuatl or pre-Columbian history, but at the same time shed light on the original place meanings of Mexico City. The Spaniards, who arrived in Central America at the beginning of $16^{\text {th }}$ century, did not establish the new capital city of the Viceroyalty of New Spain on a greenfield site, but rather upon the ruins of Tenochtitlan, ${ }^{19}$ the former capital of the Aztec Empire (Figure 4). If we take a look at these icons again, we will see the city dominated by the hill inhabited by grasshoppers, built over the salty waters of Lake Texcoco and pervaded by a network of canals, where travel was controlled by signaling flags. The city, which needed sources of fresh water and an agricultural base (which was provided by surrounding areas such as Tacubaya and Juanacatlán), had a history predating the Aztec civilization. It also entailed a history of other Indian ethnic groups such as the Toltecs, ${ }^{20}$ who founded

Despite its name, it is still unclear if it belonged to Moctezuma or not. The original headdress rests in the Museum of Ethnology in Vienna, Austria (see Breur 2002: 62; Castelló Yturbide 1993: 18).

15 Feather work was an important artistic technique in pre-Colombian America. Especially for the Aztecs, who became master feather-crafters and developed sophisticated methods of incorporating feathers into impressive objects of art (see Castelló Yturbide 1993).

16 The original Aztec form of Cuitláhuac's name is Cultlahuanctzin. His name was changed by Spaniards because of the pronunciation.

17 In the Nahuatl tongue, Chimallli means "shield" (see Fernandez 1992: 49).

18 "The Night of Sorrow" (from Spanish, „Noche Triste“) is an important event in Mexican history, referring to the Conquest. During the night of June 30, 1520, the Aztecs rose against the Spaniards and drove them out of Tenochtitlan. The surviving Spaniards allegedly felt sorrow at the loss of their companions and treasures, which they had to leave in the Aztec capital city. This is where the name of the event originated (see Bernal 2000, 2009: 241; Opatrný 2003: 28-29).

19 Tenochtitlan was an Aztec city-state called altepetl in the Nahuatl tongue. Tenochtitlan was situated in the Valley of Mexico. It was founded in 1325 and built on an island in Lake Texcoco. Soon it became the capital of the permanently expanding Aztec Empire. In 1521 Tenochtitlan was captured by the Spaniards, led by Hernán Cortés, and sacked. Mexico City was founded the same year over the ruins of Tenochtitlan. Cortés gave the new capital the name of Mexico in honor of the Aztecs, who referred to themselves as the Mexica or Tenochca people, as well (see Bernal 2000, 2009: 241-243; Vaillant 1974: 157-165).

20 The Toltec culture was a dominant Mesoamerican culture in central and southern Mexico between the $8^{\text {th }}-12^{\text {th }}$ centuries B.C. Toltec dominance over ancient Mexico collapsed because of the invasion of the Aztecs in the 12th century. The Toltecs, a Nahuatl-speaking people, founded Coyoacán in the 7 th century. Coyoacán was subsequently overpowered by the Tlatoanes and then by the Aztecs. For more on the history of Toltecs see Bernal (2000, 2009: 142-143); Vaillant (1974: 58-65). 
Coyoacán or the Tepenec, ${ }^{21}$ whose dominion Tacuba (or Tlacopan) had been, in the course of time, along with Coyoacán, absorbed by the growing Aztec Empire.

Figure 4: The map of Tenochtitlan. Attributed to Hernán Cortés, 1524

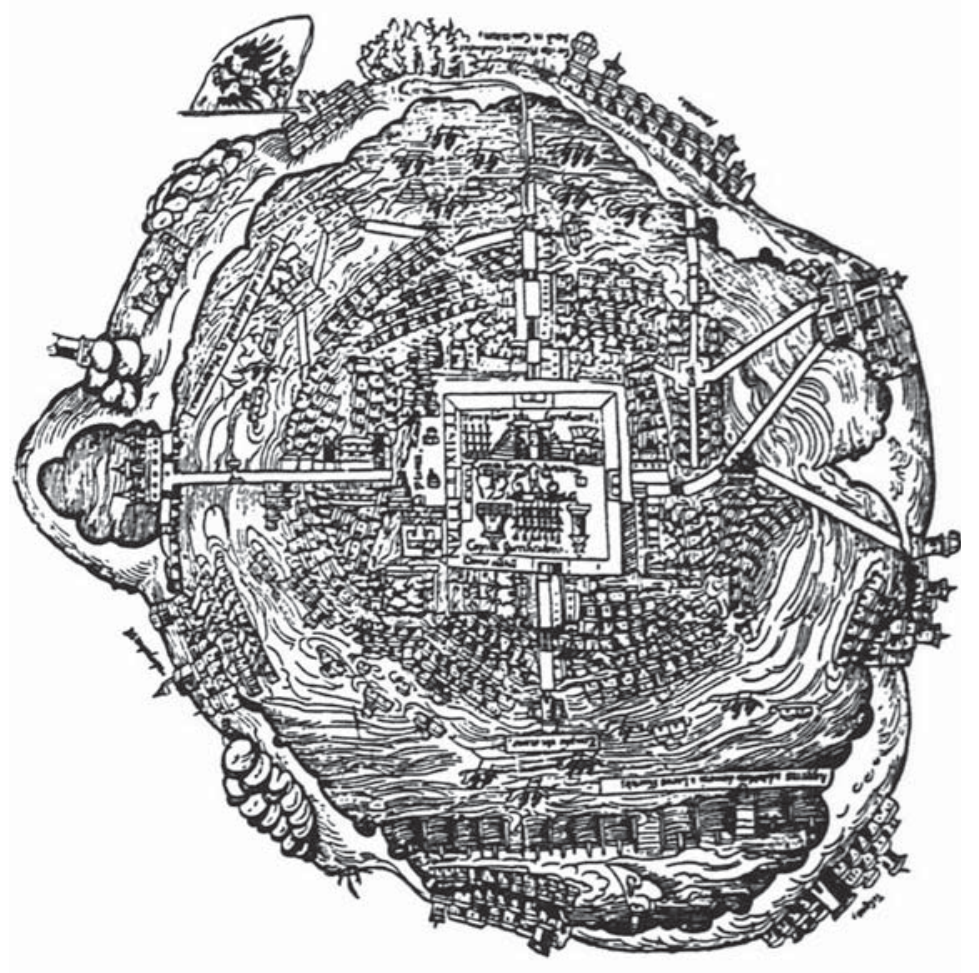

Source: adapted from Sartor, Mario. Arquitectura y urbanismo en Nueva España, siglo XVI.

\section{The Colonial Period}

The symbol of the Line 1 station "Isabela la Catlica," which bears the name of a downtown boulevard of the same name, refers to the period of discovery and conquest of the New World, which corresponds to the first half of the $16^{\text {th }}$ century. Queen Isabella I of Castile (1451-1504) financed the voyage of Christopher Columbus (1451?-1506), which originally meant to find India but eventually led to the discovery of a new continent in 1492 later called

21 Tlacopan (also called Tacuba), was a pre-Columbian city-state, which was located on the western shore of Lake Texcoco, which is today the Tacuba district. One of districts of Mexico City, D.F. Tlacopan was a Tepenac kingdom, which was subordinated to Azcapotzalco. For more on the history of Tepenac and Tlacopan, see Vaillant (1974). 
America. ${ }^{22}$ The symbol of this station portrays one of the Columbus' caravels. Another two stations also refer to this period: Popotla and Villa Cortés on Line 2, both of which are associated with the personage of Hernán Cortés, the Spaniard who conquered the Aztec Empire. The icon of Popotla station depicts an ahuehuete tree, ${ }^{23}$ whose silhouette is so characteristic of the Mexican landscape. According to various legends, Cortés cried in the shadow of this monumental tree (which today, after several fires, we can unfortunately admire only in the vestige of a trunk) after "The Night of Sorrows." The symbol of the stop Villa de Cortés named after the place where Cortés allegedly met Moctezuma for the first time - is a picture of a typical military helmet of a Spanish conqueror dating from the sixteenth century.

Gradually the Viceroyalty of New Spain which began in the second half of the $16^{\text {th }}$ century and ended in the early $19^{\text {th }}$ century, became well established during the colonial period. ${ }^{24}$ The ancient city of Tenochtitlan had been wiped off the map, and above its ruins was built the new capital city called Mexico. Its financially intensive construction was facilitated by the discovery of abundant local fields of gold and silver. Up to the present time, the most famous place of silver extraction and processing has been the city of Taxco, which gave the name to the Line 2 station Taxqueña. Its icon depicts the Moon, which is traditionally associated with silver. Also, many colonial districts still exist here, such as La Candelaria de los Patos, known for its duck market, which gave the name to the Line 1 station Candelaria, in whose symbol we recognize a floating duck. The beauty of the colonial architecture reminds us of the icon of the Line 2 station San Cosme, which is named after the homonymous avenue - it is a symbol of one of the French windows which decorates the colonial palace known as Casa de los Mascarones, an emblematic sign of this avenue. In 1779 the Viceroyal authorities decided to build an aqueduct because of the lack of fresh water. The arcades of this colonial construction - known as the Chapultepec or Belen Aqueduct - are depicted on the sign of the pink line's Sevilla station. The aqueduct brought water to the fountain known as Salto del Agua, which is (unlike the aqueduct, of which only a few arches have survived) still located downtown, and its picture forms the icon of the station.

The effort to conquer the natives was from the very beginning accompanied by the endeavor to save their souls and convert them to Catholicism. The task of the evangelization of Indians was entrusted to the mendicant orders, which seized this opportunity with great enthusiasm. The activities of mendicant orders during the $16^{\text {th }}$ century changed not only the spirituality but also the physical map of the Viceroyalty, filling its horizon with thousands of crosses, towers, monasteries, churches and chapels. This part of colonial history is represented

22 The first person to name the New World "America" was German cartographer Martin Waldseemüller in his world map dating from 1507. Waldseemüller invented the appellation, drawing inspiration from the name of the Italian discoverer Amerigo Vespucci (see Luque Alcaide 1992: 125; Opatrný 2003: 24).

23 Ahuehuete (in Latin, Taxodium mucronatum) is known as Montezuma Cypress. It is a typical tree of Mexico. Its name comes from the Nahuatl name name for the tree, ahuehuete, which means "tree, old man sleeping by the water" (from Spanish, "Árbol, viejo que duerme junto al agua") (see Fernandez 1992: 17).

24 For more on the colonial period of the History of Mexico, see Bernal (2000, 2009: 281-430). 
by the icon of the Ermita transfer station (between Line 2 and Line 12), which depicts an eremitic chapel.The icon of the San Antonio Abad station (also located along Line 2) portrays a silhouette of St. Anthony the Great (ca. 251-356), whose personage reminds us of the exmonastery of the Augustinian order (which had been situated near the station).

Figure 5: The Salto del Agua fountain, Mexico City, 18th century

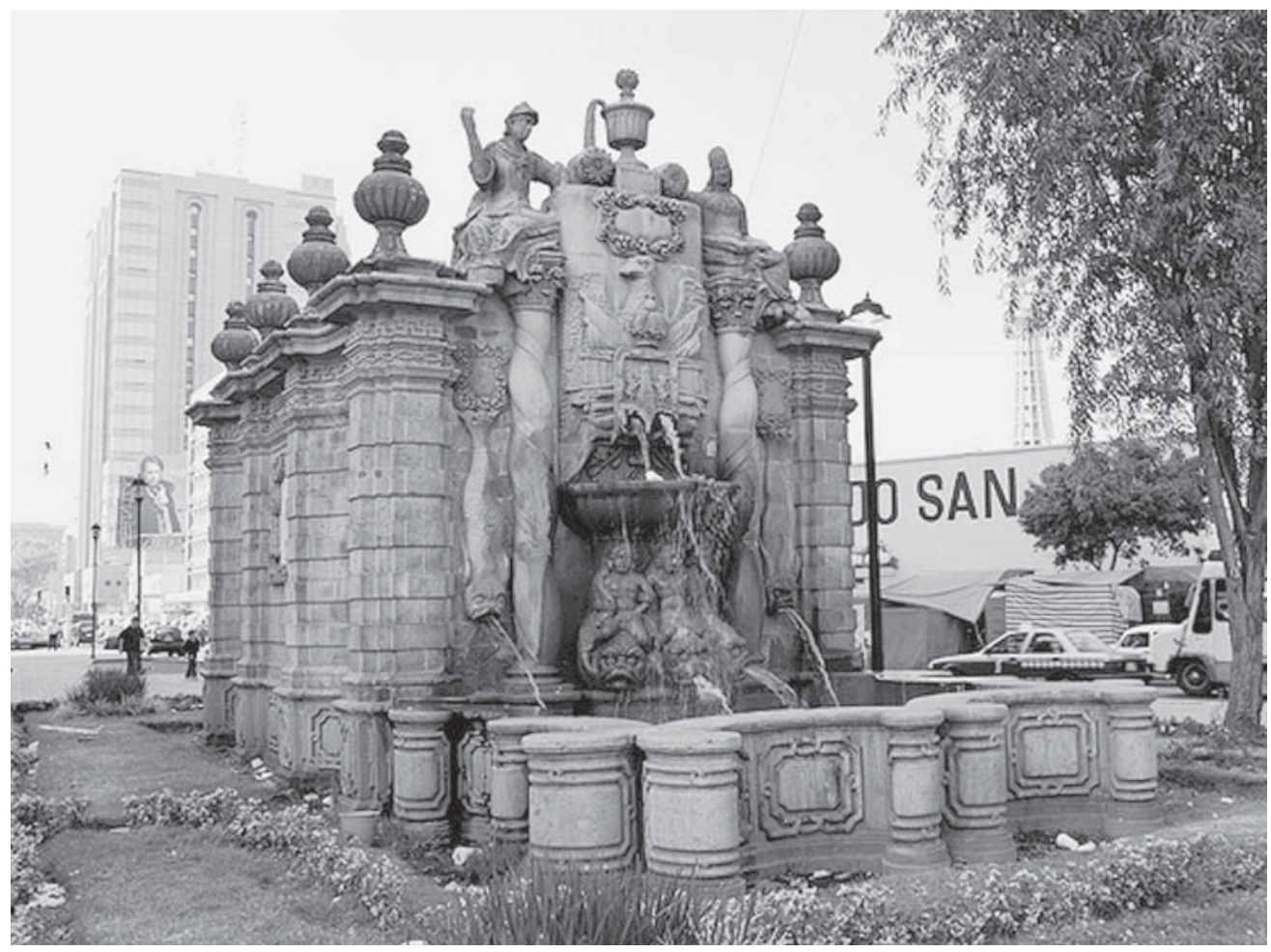

Source: Monika Brenišínová, 2013

\section{The Generation of Liberators and Founders}

Inspired by the Enlightenment, the French Revolution and the American War of Independence, and motivated by the unfair distribution of power between the colonies and the Monarchy of Spain, the idea of establishing a new independent state gained popularity with the inhabitants of New Spain in the early $19^{\text {th }}$ century. The icons of the majority of stations relating to the Mexican War of Independence (1810-1821) $)^{25}$ and to the formation of Mexican statehood

25 The Latin American Wars of Independence during the first third of 19th century was a series of revolutions, which resulted in the creation of number of independent states in Latin America (see Opatrný 1998: 667-671). 
depict a silhouette of a human figure, sometimes equestrian or a bust. These include: the first line station Zaragoza, which bears the name of General Ignacio Zaragoza (1829-1862); followed by the station Allende named after the royal army captain Ignacio Allende (17691811), who took sides with the independence movement; and the station General Anaya, bearing the name of General Pedro Maria Anaya (1795-1854). And finally, the third line station Guerrero, named after General Vicente Guerrero (1782-1831), also belongs in this group. Among all the stations referring to this period of Mexican history, the first line station Gómez Farías (1781-1858), whose icon portrays an open book inscribed with the year 1857, stands out. The book symbolizes the liberal Constitution of the year $1857,{ }^{26}$ which was tirelessly promoted by this politician and reformer. The Hidalgo interchange station between Lines 2 and 3, bearing the name of Miguel Hidalgo (1753-1811), ${ }^{27}$ the initiator and the main representative of the first period of the Mexican War of Independence, is also worth mentioning. Finally, there is the Juárez third line station, named for the most famous Mexican president, Benito Juárez (1806-1862). ${ }^{28}$

The history of the War of Independence and the foundation of the Mexican state are represented at other metro stations, as well. In particular, there is the first line station Insurgentes, named after the homonymous boulevard, whose name means "insurgents." Its icon depicts the church bell of Dolores Hidalgo, which had been used to signal assemblies of insurgents and became the symbol of the struggles for independence. And the station of the third line Niños Héroes, or "Heroic Children," which reminds us of another glorious moment of Mexican history: the unequal battle in which six teenage military cadets died while defending Mexico against U.S. troops. ${ }^{29}$ The symbol of this station is a military cap, or kepi, ${ }^{30}$ which traditionally formed a part of the former military cadet uniforms, in a festive garland.

Mexican independence was finally achieved during the Mexican Revolution (1910-1917), ${ }^{31}$ whose leaders were General Francisco Villa, better known as Pancho Villa (1878-1923), ${ }^{32}$

26 The Federal Constitution of the United Mexican States of 1857 is a liberal constitution, which was ratified by the federal government of the United States of Mexico on February 5, 1857. The constitution established many individual rights (e.g., freedom of the press, etc.) (see Bernal 2000, 2009 : 592-595).

27 Don Miguel Hidalgo was a Mexican priest, who eventually became a leader of the Mexican War of Independence (see Bernal 2000, 2009: 504-509).

28 Benito Juárez was a Mexican lawyer and politician of the Zapotec origin, elected president of Mexico five times (1858-1861, 1861-1865, 1865-1867, 1867-1871 and 1871-1872) (see Bernal 2000, 2009: 597-605, 612-616, 635-642 and 648-650).

29 The Niños Héroes are also known as the Heroic Cadets or Boy Soldiers. They were six Mexican teenage military cadets (Juan de la Barrera, Juan Escutia, Francisco Márquez, Agustín Melgar, Fernando Montes de Oca, and Vicente Suárez), who died on $13^{\text {th }}$ September 1847 in the Battle of Chapultepec during the Mexican-American War (see Opatrný 1998: 66-67).

30 The kepi (from French "képi," a version of German "kappe," meaning "cap") is a type of cap with a semicircular peak, which used to form part of French military and police uniforms, and was popular with many Latin American armies (see Larousse 1993: 357).

31 On the Mexican Revolution see Bernal (2000, 2009: 757-817).

32 The original name of Francisco Villa was José Doroteo Arango Arámbula, but he is better known as Pancho Villa. He is one of the most famous personalities of the Mexican revolution. He was 
and Emiliano Zapata (1879-1919). ${ }^{33}$ The revolution - a movement directed against dictatorship and the continuing feudal organization of the country - ended in defeat, but its emphasis on the egalitarian organization of society and distribution of land finally contributed to the development of the Mexican state. Two stations lying along Line 3 refer to these memorable historical events: División del Norte, which is symbolized by the equestrian figure of General Francisco Villa; and Zapata, whose icon portrays a bust of Emiliano Zapata wearing a typical Mexican hat called a sombrero.

\section{The Modem Era}

In the $19^{\text {th }}$ century, not only did the governmental structure of Mexico change, but also the appearance of its capital. In the manner of big European capitals, municipal authorities approached the modernization ${ }^{34}$ of Mexico City with the obvious aim of transforming the old colonial city into a modern western metropolis (Figure 6). The hacienda that surrounded the historical center disappeared from the map of the city, and in their place emerged urban sprawl. This fact is highlighted at the Line 2 Xola station, which is named after the Sola family of landowners. The icon of this station depicts a coconut palm tree, because the Xola hacienda grew this crop in large quantities. Next on the same line is the station Portales, in English "porticos," where a new urban district of the same name was built in the place of one of the largest and most productive haciendas, whose population had specialized in the production of burnt brick. These were sold in the main street Del Tabique, which was known for a series of brick porticos, and are now in the station's symbol..$^{35}$ The modernization of the city brought with it new boulevards and avenues, and alleys of fruit and ornamental trees. These provided desirable shade, as we can imagine by way of an example of the second line station Chabacano, which bears the name of the nearby avenue called Calzada de los Chabacanos. This name in American Spanish means "The Apricot Boulevard." Thus the icon of this station portrays this sweet fruit.

The authorities concentrated not only on the modernization of the city, but also on its industrialization. And they began to found and consequently build new modern construction. For example, the modern building of the main San Lázaro railway station, which used to stand on the site of the first line station of the same name, is represented by a picture of a steam locomotive. The icon of the next station of the same line, Merced, depicts a basket of apples, because a modern market hall built from steel-reinforced concrete and glass, used

a revolutionary general, in particular he was a commander of the Division of the North (from Spanish, División del Norte) (see Bernal 2000, 2009: 792-798 and 805-807).

33 Emiliano Zapata was one of the leaders of the Mexican Revolution in the Mexican state of Morelos, and the founder of the agrarian movement called Zapatismo (see Bernal 2000, 2009: 785-788, 793-798).

34 The modernization of Mexico (i.e., the construction of railways, factories and telegraphs) is related to the dictator Porfírio Díaz (1830-1915) (see Bernal 2000, 2009: 962; Opatrný 1998: 450).

35 The portico is a porch or entrance to a building, which consists of a covered columned area (see Blažíček 1991: 166). 
to stand in the place of the station. The city representatives also established many important institutions at this time, such as the National Theatre, which in the early $20^{\text {th }}$ century obtained a new residence in the Palacio de Bellas Artes (Palace of Fine Arts). It was built in Art Nouveau style, and its image is found on the icon of the first line station Bellas Artes. Another modern building is the astronomical observatory, whose silhouette can be seen in the sign of the Observatorio Line 1 station. The new military academy gave its name to the second line station Colegio Militar, whose icon depicts the coat of arms of this institution. With the modernization of the historic downtown, old cemeteries were removed and transferred to the periphery. Some of them can be found close to the second line station Panteones, which means "cemetery" in Spanish. Thus, the station icon portrays a silhouette of a grave with a cross on the top.

Figure 6: Casimiro Castro, the Parade Square of Mexico, $19^{\text {th }}$ century

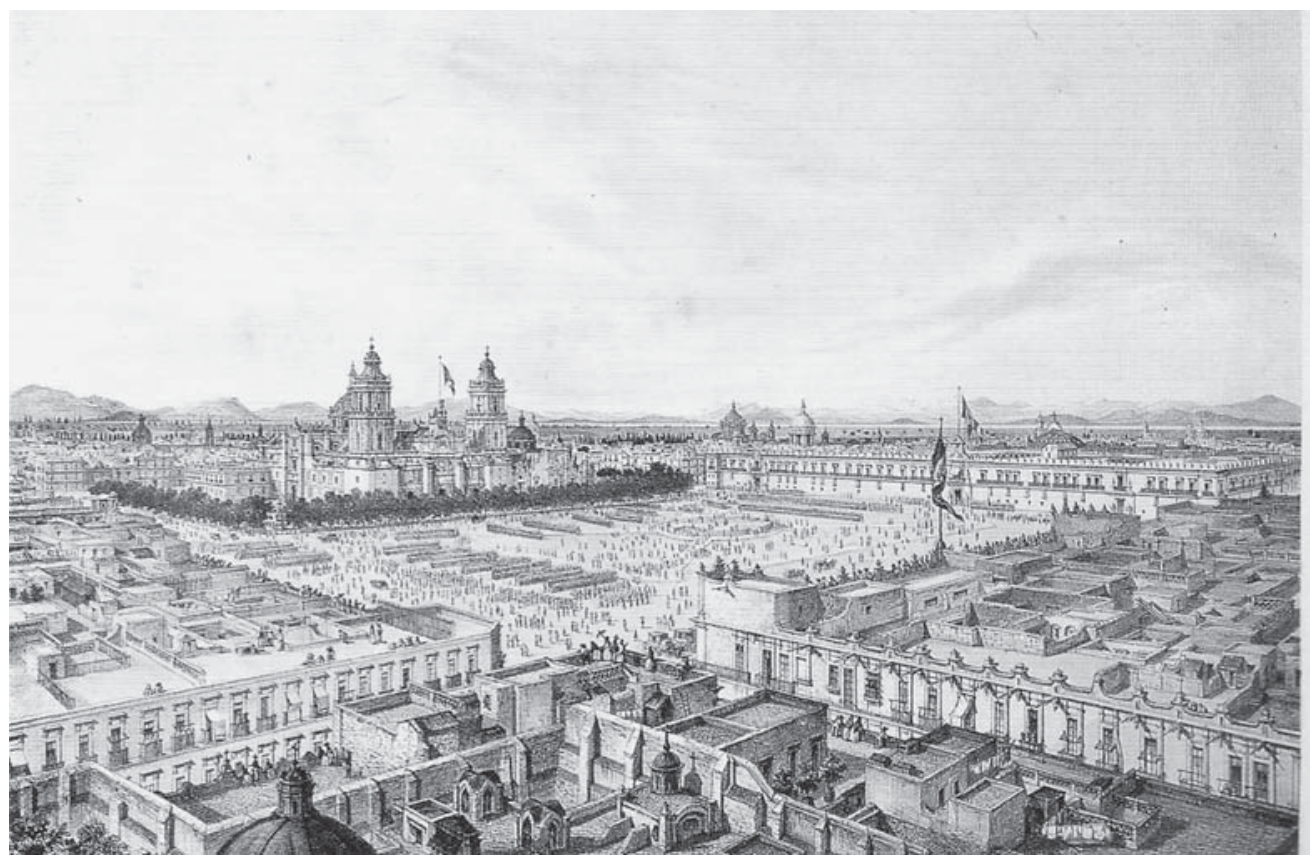

Source: Adapted from Nación de imágenes, la litografía del siglo XIX.

Urbanization brought with it an increasing interest in nature. An example of this attitude might be found at the third line station Viveros, named for the passionate conservationist and promoter of forestry Miguel Angel de Quevedo (1859-1946). He founded a tree nursery for the forestation of the capital city and its surroundings, which today serves as a park and arboretum which is also called Viveros de Coyoacán. This park gave the name to the nearby station Viveros, which is represented by a plant sprouting in the form of a dove from a pair of human hands. 
Another wave of urbanization followed in the 1950s and 60s, a time of economic boom known as the Mexican miracle. Steep population growth demanded improvements in public transport and the system of roads and highways. This caused a precipitous increase in land prices, which led to the construction of housing estates and high-rise buildings. This period of Mexican history is memorialized especially in the signage of third line stations. The most famous Mexican housing estate was built in the district of Tlatelolco. The symbol of this district as well as of the homonymous local metro station is a high-rise building called Torre Insignia. In addition, at this time numerous public hospitals were established and can be found in the names of stations such as Hospital General (the icon of this station is a white cross on a green field) and Centro Medico (whose icon depicts an international symbol of medicine: the rod of Asclepius). The internationally renowned university campus of the National Autonomous University of Mexico (UNAM), which can be found at the station Universidad, was founded and built between the years 1949-1954 (Figure 7). Its icon portrays the official emblem of the university in the form of a Mexican eagle and an Andean condor holding a map of Latin America. Also many sports grounds were constructed, such as Deportivo 18 de Marzo, located near the homonymous station, and whose icon depicts a picture of a pre-Columbian tlachtli ${ }^{36}$ ball game player. The symbol of the second line station Viaducto reminds us of the city's massive system of roads and highways, which is emblematized by a picture of the well-known four leaf clover motorway junction.

$20^{\text {th }}$ century urban planners also conceived of the Mexico City Metro system as a museum. Many stations possess display showcases and there are temporary and permanent expositions; or they are decorated by reliefs and murals by reputable Mexican artists (Ríos 1973: 69-76). In the course of the construction of the Mexican metro, many archeological finds were also discovered, especially from the pre-Columbian and Colonial times. These are now located in Mexican museum collections; however, replicas can often be seen and admired directly within the interior of the stations (Ríos 1973: 21). The best illustration of this is the metro station Pino Suárez (Ríos 1973: 73), which lies along Lines 1 and 2. Its icon depicts a pre-Columbian circular pyramid dedicated to Ehecatl, the ancient god of the wind.$^{37}$ It was discovered during the construction of the station, and can be seen in the middle of the station.

I would like also to mention that the Mexico City Metro signs have been so successful, that they have inspired other Mexican cities, such as Monterrey, where we can admire a similar system of signage. Also, Lance Wyman - after his success in Mexico City - designed similar systems of signage for other institutions such as the underground of the capital city of the United States of America, Washington, D.C.

36 The tlachtli is the Nahuatl name for a typical pre-Columbian Mesoamerican ballgame (see Fernan$\operatorname{dez} 1992: 145)$.

37 The Mesoamerican god of wind Ehecatecuhtli, who is also known as Ehecatl, is one of the advocates of the god of culture and knowledge Quetzalcoatl (see Fernandez 1992: 54). 
Figure 7: Juan O' Gorman, Central Library of National Autonomous University of Mexico, 1950-1956

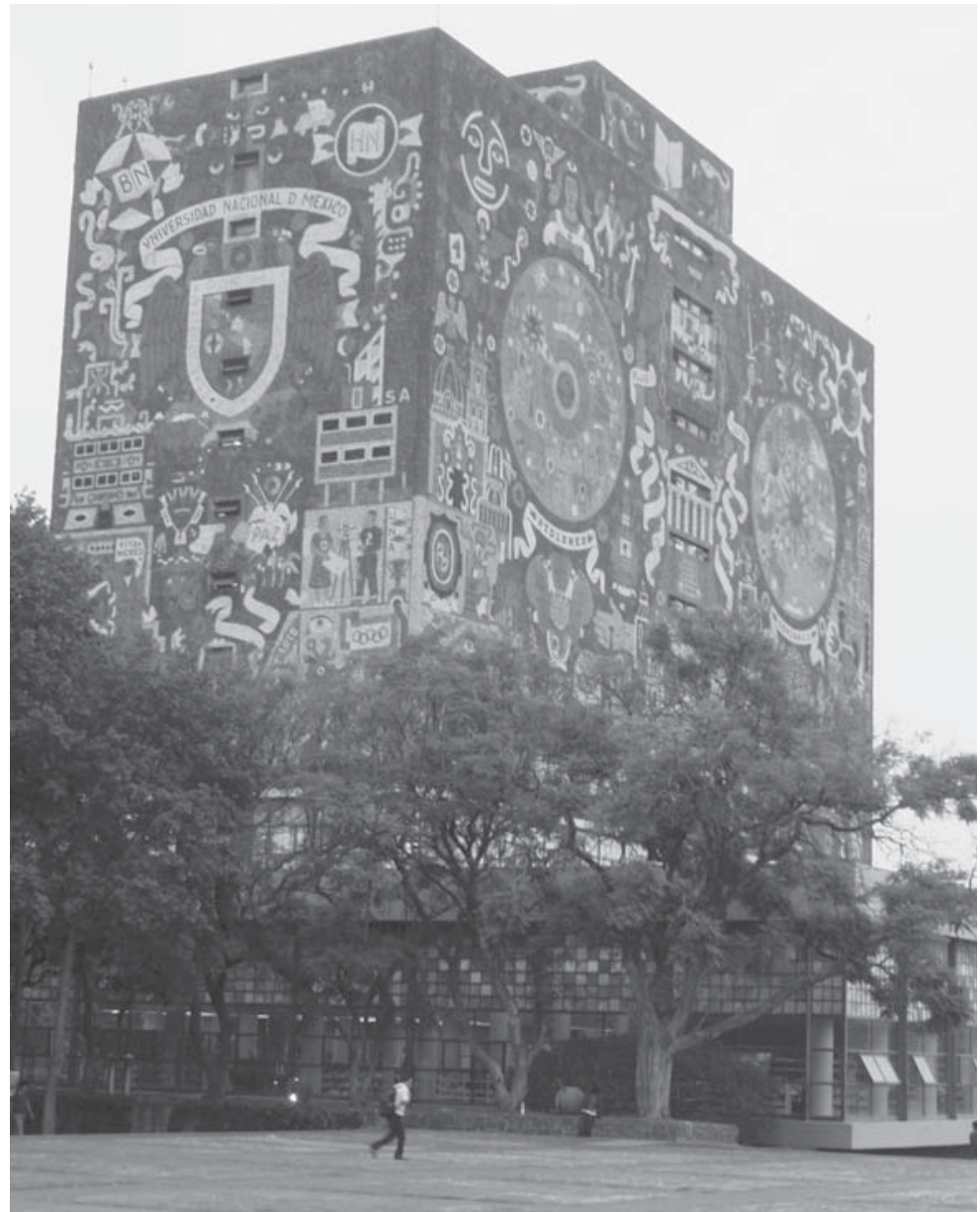

Source: Monika Brenišínová, 2010

\section{Conclusion}

Because the metro icons are not unequivocal, the system of the Mexico City Metro signage allows the passenger to attribute a different meaning to the pictures of individual stations, regardless of his or her origin, education or age. Thus the ambiguity of icons permits the orientation of foreigners, young children and illiterates in the Mexican metro and makes its system of signage unique. However, it is also important to note the difference between the everyday use of the metro and the ideological intention of its builders.

The Mexican metro was conceived and constructed during the long-ruling government of one political party - the PRI (Partido Revolucionario Institucional; in English: Institutional 
Revolutionary Party). The PRI dominated the Mexican economy, which was primarily based on the oil industry. The Mexican miracle was accompanied by a population explosion, which pointed out gaps in the Mexican government's policies (such as lack of education, health care and social systems, infrastructure, etc.). The $19^{\text {th }}$ Summer Olympic Games should have been an opportunity for the Mexican state to show its power and competence. However, in the same year the discontent of the Mexican population brought the tensions to a head and festered into social unrest, led by students. The goal of the Mexican student movement was to reform the political system in the country. The social unrest culminated on October 2, 1968 with the Tlatelolco Massacre, during which the Mexican army killed 30 people (the actual number of deaths is estimated at about 200-300 people). The Mexican government responded to the growing discontent of the population by strengthening its economic role and populism. In an attempt to remain in power, and to avoid more costly reforms, the PRI chose to invest in public buildings. Thus the construction of the Mexico City Metro should be viewed as a showcase of the Mexican state, which shows Mexico as a strong, modern state that cares about its citizens.

We have seen that the Mexico City Metro sign system - and in particular the icons of its stations - offers to its users more than a simple orientation to the labyrinth of Mexican metro lines and stations: it offers a unique insight into the soul of the city (at least during the time of the construction of the metro, i.e., in the last third of the $20^{\text {th }}$ century). To conclude, the Mexico City Metro signage shows us that Mexico, as a nation, is proud of its pre-Columbian history. Mainly, it is proud of the Aztec Empire and its lacustrine capital Tenochtitlan, and appreciates the colonial period, which brought with it Western culture and Christianity. It is especially proud of the generation of liberators and founders of the independent Mexican state. Finally, it teaches us that the most common things (when approached as a symbolic communication system), such as the metro plan in this case, can be of larger informational value than might be expected.

\section{Lterature}

ALCAIDE Luque, Elisa and José-Ignacio SARANYANA. 1992. La Iglesia católica y América. Madrid: MAPFRE.

BERNAL, Ignacio, ed. 2009. Historia general de México. México, D.F.: El Colegio de México.

BLAŽÍČEK, Oldřich J. and Jiří KROPÁČEK. 1991. Slovník pojmů z dějin umění: názvosloví a tvarosloví architektury, sochařství, malby a užitého umění. Prague: Odeon.

BORJA Navarrete, Angel. 1997. Treinta años de hacer el Metro: Ciudad de México. México, D.F.: Ingenieros Civiles Asociados, Espejo de Obsidiana.

BREUR, David and Maria Luisa BALSEIRO. 2002. Aztecas. México: Océano: Consejo Nacional para la Cultura y las Artes, Instituto Nacional de Antropología e Historia.

CASTELlÓ YTURBIDE, Teresa. 1993. El arte plumaria en México. México, D.F.: Grupo Financier Banamex-Accival: Fomento Cultural Banamex.

FERNANDEZ, Adela. 1992. Diccionario de voces nahuas: definiciones de palabras palabras que expresan el pensamiento mítico y religioso de los nahuas prehispánicos. México, D.F.: Panorama.

LUQUE ALCAIDE, Elisa and José-Ignacio SARANYANA. 1992. La Iglesia católica y América. Madrid: MAPFRE. 
OPATRNÝ, Josef. 1998. Amerika v proměnách staletí. Prague: Libri.

OPATRNÝ, Josef. 2003. Mexiko. Prague: Libri.

PANOFSKY, Erwin. 1981. Význam ve výtvarném umění. Translated by Lubomír Konečný. Prague: Odeon. RÍOS, Juan Francisco. 1973. El Metro de México: primera Memoria. México, D.F. : Sistema de Transporte Colectivo -METRO-.

ROMERO, Héctor Manuel. 1987. Historia del transporte en la Ciudad de México: de la trajinera al metro. México, D.F. : Departamento del Distrito Federal, Secretaría General de Desarrollo Social.

VAILLANT, George Clapp. 1974. Aztékové. Původ, vzestup a pád národa Aztéků. Translated by Václav Šolc. Prague: Orbis.

\section{Sources}

DPT (DOPRAVNÍ PODNIKL HLAVNÍHO MĚSTA PRAHY). No date. Dopravní schémata. Accessed. April 5, 2014 (http://www.dpp.cz/dopravni-schemata/).

INEGI (INSTITUTO NACIONAL DE ESTADÍSTICA Y GEOGRAFÍA). No date. Dinámica. [Accessed April 5, 2014 (http://cuentame.inegi.org.mx/monografias/informacion/df/poblacion/dinamica. aspx?tema $=$ me\&e $=09)$.

INEGI (INSTITUTO NACIONAL DE ESTADÍSTICA Y GEOGRAFÍA). No date. Analfabetismo. Accessed April 5, 2014(http://cuentame.inegi.org.mx/poblacion/analfabeta.aspx?tema=P).

INEGI (INSTITUTO NACIONAL DE ESTADÍSTICA Y GEOGRAFÍA). No date. Lenguas indígenas en México y hablantes (de 5 años y más) al 2010. Accessed April 5, 2014 (http://cuentame. inegi.org.mx/hipertexto/todas_lenguas.htm).

STC (SISTEMA DE TRANSPORTE COLECTIVO). No date. Decreto de Creación del Sistema de Transporte Colectivo. Accessed April 5, 2014 (http://www.metro.df.gob.mx/organismo/mjdecreto.html).

STC (SISTEMA DE TRANSPORTE COLECTIVO). No date. Estaciones. Accessed April 5, 2014 (http:// www.metro.df.gob.mx/red2/index.html\#es).

STC (SISTEMA DE TRANSPORTE COLECTIVO). No date. Plano de red web. Accessed April 5, 2014 (www.metro.df.gob.mx/imagenes/red/redinternet.pdf).

WYMAN, Lance. 2004. “Case Study. Lance Wyman.” In Webesteem magazine Accessed April 5, 2014 (http://art.webesteem.pl/9/wyman_en.php).

WYMAN, Lance. 2005. “Mexico City Metro Logo.” Accessed April 5, 2014 (http://www.lancewyman.com). WYMAN, Lance. 2005. "Mexico'68 Olympics.” The Logotype. Accessed April 5, 2014 (http://www. lancewyman.com.).

\section{Author}

Monika Brenišinová is a Ph.D. student at the Centre for Ibero-American Studies at Charles University in Prague, where since 2014 she has lectured on the history of Latin American art. In 2013 she spent one year in Mexico doing field research on the topic of $16^{\text {th }}$ century New Spain monastic architecture. At present, she is working on two grant projects: "History of Art of Latin America" and "Architecture of the Conversion in the Process of Conquest and Colonization of the New World." Since 2012 she has served as the editor of the Človék Časopis pro humanitni a společenské vědy (http://clovek.ff.cuni.cz/index.php) and at the same time as the webmaster of the official website of the Centre for Ibero-American Studies (http://sias.ff.cuni.cz/SIAS-1.html).

Contact: MonikaBrenisinova@seznam.cz 